\title{
The Vendée Globe: a fair deal, for the sustainable development of Sables d'Olonne?
}

\author{
M.-M. Damien \\ TVES Laboratory, University de Lille 1, France
}

\begin{abstract}
The Vendée Globe is becoming a mythical event for Sables d'Olonne. It is the "Vendée Blue Gold!", which is how we know it today. In 2014, the Vendée Globe was considered a fascinating event, self-made by the area, so it may be considered as Vendean Heritage, well identified and developed by all the inhabitants who are able to participate and collaborate in its success. They are really proud of it. It is an excellent example of a sustainable tourism project and a successful event created by local people. Vendée Globe is today a landmark.

How has this famous event galvanized and is continuing to galvanize people for action towards sustainable development of the city and its surrounding region? It has generated a real urban and country metamorphosis and a new local dynamic since 1989 and has changed attitudes.

To study this evolution, the common methods and participative techniques that have been used or are still used across both categories: interviews: individual and in depth (100/year ante and post and during the event), focus groups with stakeholders and partners took place during each phase and episode of Vendée Globe. Elements as indicators have been chosen and analyzed after every race to try to estimate internal and external effects on the territory and landing management. But will the management of the race escape from its local partners in the future?

Keywords: alone race, no call, round the world, sustainable tourism, sponsoring, indicators, ex-ante evaluation, evaluation during the event, ex-post evaluation, association, impacts.
\end{abstract}

\section{Introduction}

An event organized every four years, the Vendée Globe is really becoming a mythical event for Sables d'Olonne, a tiny and popular seaside resort along the 
Atlantic Coast, in Vendée, in the Pays de la Loire region. This city, dedicated to mass tourism in the sixties and seventies is now catering to a range of more demanding visitors who can be characterized as connoisseurs, far from the ordinary tourist striving for discounts, cheap hotels and ravishing parties.

Now, it has become more and more popular. Its appealing power enjoyed by this exceptional sportive event grows from strength to strength. More and more people are attracted to this exceptional and free access event. The port wharfs are becoming very crowded. This small city with its 18,000 inhabitants welcomes 800,000 visitors in a single day. For sure, it's a great achievement, of which the local community can be more and more proud! But is it sustainable for the inhabitants? Is it an environmentally friendly event? What are the impacts of the event in terms of business carried out and projects launched but also in terms of environmental effects? We have been trying to identify and determine its positive and negative adverse effects. What are the key lessons we can learn that make this event become a successful sustainable event? How has it authorized a sustainable urban evolution of the seaside resort and its surroundings?

\section{A local event born randomly, sustainable by itself by its federative network}

\subsection{The sailing Vendée Globe race concept}

It is a simple story which started by chance in 1989, between two men, a sailor Quimpero-Olonnais Philippe Jeantot and Sables d'Olonne's mayor, Gerard Guesdon, but also a woman, Annette Roux, team Beneteau's manager. This sailing race concept was developed randomly, without any event agency by Philippe Jeantot when he was celebrating his 2nd rank during the New Port-Le Cap call: an idea born in South Africa, at Cape Town on 11th October 1986! It was the beginning of his dream. After two events, the race was under threat of disappearing because of financial reasons. But fortunately, Vendée General Council President, P. Devilliers saved it and named it "Vendée Globe". This extraordinary choice was an excellent marketing operation, which the General Council has done for all local activities (nautical industries, tourism, leisure) and their context (valorization of the lore and landscapes). Environmental protection acts were applied: Natura 2000 and new walking areas managed..... It was the beginning of a new deal, the current Vendée and Sables d'Olonne started waking up!

In fact, during six months from November to March, and even up to May with the Great Cup Festival, every day, and all round the world, we can see and hear about Vendée Globe. There is no better land marketing action for a weak and shared investment. It was really an excellent opportunity.

This made each inhabitant proud. Everyone, every village connected to the seashore or to the retro-seashore territory, started to rediscover its identity. It was the beginning of a mental revolution, the Vendean people, already proud of themselves and their tradition have become more and more proud. The cultural 
differences between the coastal inhabitants and the bocage people were swept away by the Vendée Globe. An incredible melting-pot that had waited for centuries began to operate, the Vendée Globe is the true human cement!

In fact, this psychological and social fracture appeared in the Middle Ages when the marshes were drained by the abbeys because the monks were very demanding at times. Then, later, it was necessary to recall the fratricidal wars between Catholics and Protestants. These tragic wars brought mental and territorial differences and dug a deep ditch between the interior people named the "bocage" people and the coastal communities. This problem was amplified by the civil Vendée wars during the French Revolution.

\subsection{From an individual idea to an anchored and sustainable concept}

This ambitious race project of 43,000 kilometers round-the-world without any call for assistance was first named the Globe Challenge. Annette Roux, the dynamic and jovial Beneteau manager, could bring together the seaside shore and the inland territory people by utilising her nautical plants situated along the Vendean Atlantic coast and those located in the interior (Les Herbiers). So, this race became the Vendean race and used the Beneteau company's world basis as much as possible.

For the first race in 1989, two problems had to be resolved: the fishing port channel had to be dried by up to 7.50 meters, a municipal issue, and the race budget had to be found. No one had any experience. It was an adventure for everybody. So, it was necessary to mobilize a great number of actors and inhabitants to cope with the challenge. Triumivir's meetings and actions were very important and decisive: Gerard Guesdon created a synergy between public actors (the General Council, CCI,.....) and Annette Roux with the private sector (sponsoring enterprises, banks ...) and together, by their charisma, with a great number of public or religious associations; Philip Jeantot, initiator and "designer" with the skippers, the shipbuilders, the shipbuilding architects... So, solid bases have been given to the race, anchoring it deeply for the future. Everyone wanted the Globe Challenge to become a famous sportive event. The first impact was the new marina channel, a basis for future oceanic or transoceanic races. So, we must include the increasing attraction and the economic effects, especially on employment. In February-March 1990, it was already, a success and, this race had become legendary.

\subsection{The Vendée Globe: an asset to the city and the Vendée}

Nothing marks this small port and seaside resort out - a fishing, small commercial and pleasant port with its popular seaside resort to welcome such an event, except the inhabitants had long been fond of sailing boats - for two centuries - and enjoyed themselves with marine festivities, "Their Heritage"'!...This project was quickly adopted and they supported it at once. But what a surprise! It is a social revolution. For the first time, the "bocage" inhabitants agree with the shoremen, they name them, their "little brothers", when they were "enemy brothers" yesterday! The interior inhabitants are 
becoming so fond of this event that this sailing race is running the risk of becoming Puy du Fou's race? Puy du Fou dreams of it. So, it was expected that the Sables d'Olonne municipality would be won in 2014 by their candidate. However, this did not happen.

This event belongs to the inhabitants and they feel proud of it. It has its own local anchorage and is now an exceptional event! Ever since the third event, the Globe Challenge has been named the Vendée Globe Challenge, an idea of Devilliers and an excellent departmental marketing plan for worldwide communication. The Vendée Globe Challenge is supported by every single Vendean, henceforth, the entire Vendée community is with Vendée Globe. A group of local, public or private partners work together for the Vendée Globe Challenge Race every four years.

Table 1: $\quad$ Second Vendée Globe (1992-1993), institutional and private actors' investments (Source: Vendée Globe SEM; realization: M.-M. Damien.)

\begin{tabular}{|l|c|}
\hline \multicolumn{1}{|c|}{ Partners } & Average amount of contribution \\
\hline Vendée General Council & $380,000 €$ \\
\hline Sables d'Olonne Town & $240,000 €$ \\
\hline Industry Trade Chamber & $150,000 €$ \\
\hline Crédit Agricole (Bank) & $150,000 €$ \\
\hline Regional Council of Pays de la Loire & $75,000 €$ \\
\hline Total & $\mathbf{9 9 5 , 0 0 0 €}$ \\
\hline
\end{tabular}

A semi-public company was founded by the President of the Vendean General Council with a capital of $2,500.000 €$. Its shares are held by a pool of Vendean businesses, but $54 \%$ by the Vendean General Council, $20 \%$ by the city of Sables d'Olonne and $18 \%$ by a group of 29 Vendean businesses and $8 \%$ by the Pays de La Loire region. Sables d'Olonne is the city where the Vendée Globe the sailing race starts and the final sailing race is managed by this municipality as the Vendée Globe village located on the document (Figure ${ }^{\circ} 1$ ).

On 23rd February 2004, it was agreed that the Vendean SEM (semi-public company) could use the brand, Vendée Globe, by the civil court and, this brand was registered as a trademark. The experienced and skilled sailor Denis Horeau, was nominated as the race manager. He had been the manager of the Figaro sailing race for a long time.

Hence, the Vendée Globe 2004 (Table 2) obtained an operating budget of $4,500,000 €$, and attributes a reward of $475,000 €$. It is described as the world's best race but the one of the most difficult. 


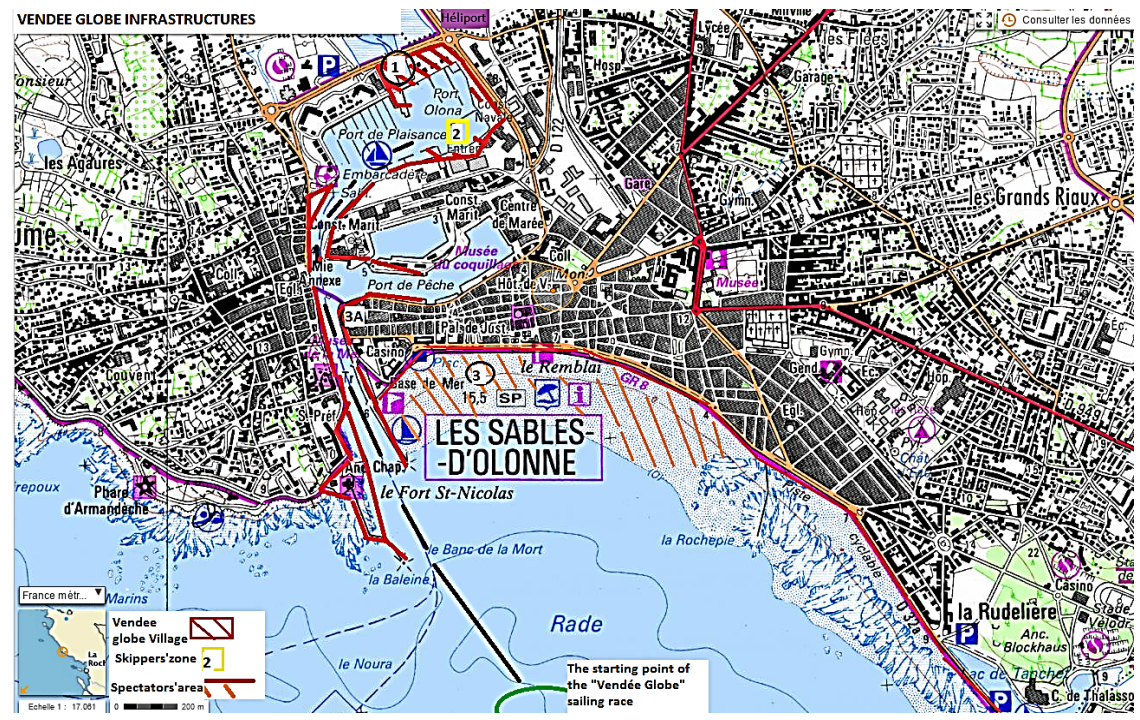

Figure 1: Event sites. (Source: Geoportail; realization: M.-M. Damien.)

Table 2: Vendée Globe 2004-2005: partners' commitment in the young SEM. (Source: S.E.M.; realization M.-M. Damien.)

\begin{tabular}{lc}
\hline \multicolumn{1}{c}{ Partners } & Participation \\
\hline Vendée General Council & $54 \%$ \\
\hline Loire Countries Regional Council & $8 \%$ \\
\hline Sables d'Olonne Town & $20 \%$ \\
\hline 29 Enterprises & $18 \%$ \\
\hline
\end{tabular}

Table 3: From Globe Challenge to Vendée Globe Challenge to Vendée Globe. (Source: S.E.M.; realization M.-M. Damien.)

\begin{tabular}{|c|c|c|c|c|}
\hline Race/name & Date & \multirow{2}{*}{$\begin{array}{c}\text { No. of boats } \\
\text { departure }\end{array}$} & \multirow{2}{*}{$\begin{array}{c}\text { No. of boats } \\
\text { back }\end{array}$} & \multirow[t]{2}{*}{$\%$ listed } \\
\hline & & & & \\
\hline 1 Global Challenge & $1989-1990$ & 13 & 7 & $54 \%$ \\
\hline 2 Global Challenge & 1992-1993 & 16 & 7 & $47 \%$ \\
\hline 3 Vendée Globe Challenge & 1996-1997 & 15 & 6 & $40 \%$ \\
\hline 4 Vendée Globe & $2000-2001$ & 24 & 15 & $62 \%$ \\
\hline 5 Vendée Globe & 2004-2005 & 20 & 13 & $65 \%$ \\
\hline 6 Vendée Globe & $2008-2009$ & 30 & 11 & $37 \%$ \\
\hline 7 Vendée Globe & $2012-2013$ & 20 & 11 & $55 \%$ \\
\hline 8 Vendée Globe & $2016-2017$ & 23 & & \\
\hline
\end{tabular}




\section{Exceptional local management and new sustainable rules and strategies for development of the seaside resort}

\subsection{Exceptional local management}

Seven races consolidated this organization (Tables 3 and 4). The seventh race was a business race! Always higher, even further, the exceptional 2012-2013 Vendée Globe pushed the boundaries of all records: sporting; recorded first as this event saw the accolade of not only the youngest winner of the race, but also the fastest one (Table 4), under the legendary mark of 80 days, according to Jules Verne. This victory came after the most tightly fought duel in the race history and is now etched into global memory. Media records too as the race echoed around the world thus becoming the offshore sailing race followed worldwide and the French sporting event with the biggest media impact, more than Roland Garros and Tour de France. There were peak audiences at the start and at the arrival, but the three months of racing are largely followed and commented on. The Vendée Globe brings together people who are passionate about extraordinary human adventures and sporting endeavour. Will the 8th Vendée Globe 20162017 push the limits even further? The Vendée People (associations), the General Council of Vendée, the City of Les Sables d'Olonne, the SODEBO group and more and more companies and many private sponsors as part of this project of which values are the Vendée's D.N.A.: commitment, courage, audacity, solidarity, surpassing oneself, team spirit ... This race is less expensive (Table 5) than, for instance, the Barcelona World Race, race in duo round the world without call (15 Mio€) and La Route du Rhum 2013 (8.7 Mio€) (Table 6). Its principal actors are local. This is the only French sporting event owned by an institutional owner.

Table 4: $\quad$ Records. (Source: S.E.M.; realization M.-M. Damien.)

\begin{tabular}{|c|c|c|c|c|c|}
\hline Race & Year & Winner & Nation & Boat name & Time of the trial \\
\hline 1 & 1989-1990 & Titouan Lamazou & France & \multirow{2}{*}{$\begin{array}{l}\text { Ecureuil } \\
\text { d'AquitaineII }\end{array}$} & 109j8h47'55" \\
\hline & & & & & \\
\hline 2 & 1992-1993 & Alain Gauthier & France & Bagages Superior & 110j17h20'8"' \\
\hline 3 & 1996-1997 & Christophe Auguin & France & Géodis & $105 \mathrm{j} 20 \mathrm{~h} 31^{\prime}$ \\
\hline 4 & $2000-2001$ & Michel Desjoyeaux & France & PRB & 93j3h57'32” \\
\hline 5 & 2004-2005 & Vincent Riou & France & PRB & $87 \mathrm{j} 10 \mathrm{~h} 47^{\prime} 55^{\prime \prime}$ \\
\hline 6 & $2008-2009$ & Michel Desjoyeaux & France & Foncia & 84j3h9'8"' \\
\hline$\overline{7}$ & $2012-2013$ & François Gabart & France & Macif & $\overline{78 \mathrm{j} 2 \mathrm{~h} 16^{\prime} 40^{\prime \prime}}$ \\
\hline
\end{tabular}

\subsection{A sustainable event on a local and departmental scale: a real inhabitant involvement}

The people of Les Sables d'Olonne and surroundings, loyal supporters and more than a thousand volunteer actors involved in an association, since the beginning of the adventure, are largely participating in the reputation of the solo non-stop round the world race by being present for every arrival of the stout-hearted 
pioneers and by helping with the organization (flow-management; parkingmanagement, accommodation, catering, supplying) at all hours. Joy, anticipation, powerful emotion and apprehension are experienced but also efficiency, under the scrutiny of national and international media, are part of their story.

Table 5: Vendée Globe 2012-2013: S.A.E.M and partners. (Source: S.E.M.; realization M.-M. Damien.)

\begin{tabular}{|l|l|}
\hline Partners & Participation (Mio€) \\
\hline \hline General Council of Vendée & 3.6 \\
\hline \hline City Sables d'Olonne & 1.270 \\
\hline \hline Industry Trader Chamber & 0.300 \\
\hline \hline Sodebo & 2.934 \\
\hline \hline Other partners & 0.456 \\
\hline \hline Derivatives & 0.206 \\
\hline \hline
\end{tabular}

Table 6: A relative budget.

\begin{tabular}{|c|c|c|c|}
\hline \hline Race & Budget Mio€ & Race & Budget \\
\hline \hline 1989 & 1 & 2004 & 4.7 \\
\hline \hline 1992 & 1.4 & 2008 & 8.2 \\
\hline \hline 1996 & 2.5 & 2012 & 8.7 \\
\hline \hline 2000 & & 2016 & $9.5 ?$ \\
\hline
\end{tabular}

Among the skippers' sponsors, several are local as PRB and Frank Vallee (Initiatives Cœur) for a long time and K-Line for six years, with media impacts, supporting children with heart defects to have surgery. Several others have been sailing partners for more 25 years, such as Banque Populaire. This company enriches itself from these extraordinary adventures that develop values of courage. Every major skipper sponsor must invest in Vendée in exchange, as Louis Vuitton did. For this 8th race event, Rothschild Bank is perhaps the most famous of the newcomers! These investment projects are creating employment and reducing unemployment. For better observation of the impacts we have set up a pragmatic and adaptable methodology since the beginning of the race in 1989.

\section{What are the indicators to measure sustainable impacts: an excellent management tool for the city and its surroundings?}

Method [1] focuses on the collection and analysis of data: quantitative or qualitative; they may attempt to describe, explain, predict or inform action. The choice of methods follows from the nature of the intervention, the evaluation questions being asked and the mode of enquiry - exploratory. The output indicator is an indicator describing the "physical" product of spending resources 
Common methods and participative techniques are used across both categories: interviews: individual and in depth interviews (100/year ante and post and during the event), focus groups with stakeholders and partners for each phase. We also use written text: archival, publications, books and we analyze press articles, drawings or photographs, videos and observation such as participant observation and non-participant observation; sometimes role-playing. On the other hand, we process the surveys: questionnaires directly administrated or indirectly at different places in the city at the start of the race and at the finish of the race but also after and before this event. We so analyze existing data.

To analyze the effects of Vendée Globe we chose a selection of 9 results' indicators in addition to monitoring indicators.

\section{1) Global access indicators}

a) International, national, intraregional: train, road, air;

b) Local: bus, soft mobility.

Mode of transport used by tourist: rail, road, air.

Mode of transport used by visitor: rail, road, air, bicycle, pedestrian.

\section{2) Monitoring indicators of exposure [4]}

a) Partners' commitment: number of partners? Patterns? Origin? Participation percentage? Pressure on the sponsor? How long have they been players?

b) Number of sponsors? Patterns? Motivation of the sponsors? Fame? Origin? Direct and indirect investments? Media impacts?

c) Visitors:

- Number of visitors for each phase and during the race: just before, at the start, between the start and the finish? And after.?

- Origin? Local? Regional?

- Motivations for each phase;

- The event feeling: give or name 3 adjectives to appreciate this event;

- Do you come once, twice, three times or more for this edition?

d) Tourists

- Number of tourists? For each phase and during the race: just before, at the start between the start and the finish? And after;

- Motivations: for each phase;

- The event feeling: give or name 3 adjectives to appreciate this event;

- Geographical origin: regional, national, international?

- Accommodation: hostel, lodge, camping, camping-car...;

- Length of stay;

- Do you come once, twice, three times or more for this edition?

\section{3) Media and fame}

- Media coverage and value: television hours; radio hours; press articles; internet use;

- Number of states; number of continents.

\section{4) Economic indicators}

a) Visitor and tourist expenditure/day; b) Temporary jobs; c) Jobs creating before the race; during the race; and after 
d) Unemployment evolution?

e) Establishments of business: number of implantations in the city and surroundings; in the department of the Vendée; increasing industrial areas...;

\section{5) Land management}

6) Social-cultural indicators

a) Involvement ; b) Changes of mentality; c) Modernity; d) Pride.

7) Technical and scientific

8) Environmental indicators

9) Risks: immaterial, material = "The more raging the storm is, (2003), the more the Vendée adopts it! Sustainable (waste ....), social (land pressure) swept by the crisis in 2016 .

\section{Results: the new rules for the city management and its metamorphosis}

\subsection{Considerable indirect effects}

\subsubsection{Better accessibility}

With the third edition and the Parisian PC established near Paris-Montparnasse, the economic impacts are more and more important. The railway station of Les Sables d'Olonne has been served by high-speed trains since 2000; and a new railway-line was built and managed in December 2008 to cut the transit time Paris-Les Sables by one hour. The town is joined to the A 87 by an expressway. Finally, by road and by train, the transit-time between Paris les Sables is cut by a third. A heliport is established nearby the Olona marina instead of the old sewage treatment plant which is rebuilt far away in 2007. Private jets can land at SaintJean d'Orbestier airport at six kilometers from the heart of the city. Nantes airport is used by international tourists who combine air-train or air-car (Motorway A11).

Just before, the last Globe Vendée, the township upgraded its health services by building of a modern heath pole: a hospital and a private clinic. The municipality decided an ambitious urban planning with the restoration of public spaces, particularly "le Remblai", Sables d'Olonne's "promenade des Anglais". Assessments: in urban and rural district have been realized to spread the visitors and treat carefully the environment of bicycle paths and footpaths we created through the forest and the swamps.

\subsubsection{A new economical dynamism}

An entrepreneurial dynamic is created! Three Vendéepôles" are developed: les Sables d'Olonne, Saint-Gilles-Croix de Vie, Challans. We have observed the setting up of 255 companies since 1992 and the creation of 8,478 jobs among them 2,948 jobs by exogenous companies; for instance, by luxury companies such as Louis Vuitton and famous Parisian fashion designers and numerous nautical or para-nautical sub-contractors, a cluster has been developed along the seaside from the Sables d'Olonne to Saint-Gilles-Croix-de-Vie, it is working in 
phase with the interior cluster of les Herbiers. This process is going on in spite of a very strong crisis. It is an important development for Vendée with a company for 16 inhabitants (national average: 1 for 26); unemployment is running with the crisis at $8.7 \%$ in 2015 , it is lower than the regional unemployment in Pays de La Loire $(9.1 \%)$, the best of all the French regions and lower than unemployment in France $(11 \%)$. Nautical industries are strengthening as the shipbuilding. But this increasing attraction has generated an exacerbated pressure for real estate. Urban planning has to reduce this effect by keeping some areas for inhabitants that and everybody owns his little house. This results in a demographic dynamism where this area attracts more and more new residents.

\subsubsection{A more and more attractive city}

Of course, the direct and indirect impacts on the tourist industry are very important. Vendée Globe is a brand image for all. The city of the Sables d'Olonne is now a major nautical destination. This race is for it a true leverage in terms of reputation ( $90 \%$ rate). Media impacts are colossal for Vendée, les sables d'Olonne and each partner. The media coverage of this Vendée Globe 7 th race is The visitors and tourists are more and more numerous to come at each phase of the race. They are fond of this event, and, become regular visitors and tourists. The flows of cars and coaches have been controlled and checked. The visitors come from all the communes of Vendée, from the region pays de la Loire, and the tourists from all the French regions, from all the European states, but also more and more from Australia, New-Zealand, America, Asia (Japan, China). Chinese people want to see what is going on and learn about the Vendée Globe spirit and to bring this sailing spirit to China and to Asia. For the next race, Jean Pierre Dick has put on the Vibrac-Paprec 3s mast a proverb from Lao Tseu in Chinese calligraphy. So 400,000 persons per day are going to visit the village and admire the skippers' boats, but for the start of the race about 800,000 people, locals and visitors, will invade the piers, docks and the beach (Figure 3 ). It is the blue gold of les Sables d'Olonne, each visitor is spending $30 €$ per person per visit and each tourist $80 €$ per person per day. They are two or three million of which one third are tourists and two thirds are visitors (140 Million€).

\subsection{More and more impacts on local strategies of development}

If the positive impacts are more and more important and if this event enjoys a surge of popularity, this huge interest does not disappear. Everybody is very proud of it. Public involvement is increasing more and more. This event is every inhabitant's business. Local priests, teachers, sailors, local merchants, craftsmen, young people adults and seniors are involved in Vendée Globe - it is their Vendée Globe. The spectators are more and more numerous and seem to enjoy themselves.

To strengthen Sablaise identity, it is important for the municipality to increase activity in which all the inhabitants, youth and elders, have to be involved, thereby creating in various sectors: cultural activities such as sculpture exhibitions, an excellent display of marine paintings in the Museums, which are held in Les Sables d'Olonne until the skippers come back. This act aims to retain 
visitors and tourists. Other artistic manifestations (creativity, design) take place everywhere. The flow of visitors and tourists out of the Vendée Globe village can be channeled and the impacts diffused by also generating visitor and tourist interest to discover the character of surrounding cities: museums, exhibitions, craftsmen (stained-glass windows and glass-works such as skippers' sailing boat models and so on), concerts and shows. In addition, merchandising and new and various products: tee shirts, clothes and biscuits, cookies, sweets and specific jewels are sold in the village near the port.

This event has shaped in a long-lasting way the attitudes and practices of communities. The contrasts of way of life between the coast-dwellers and the interior inhabitants disappear.

So, this event has a very important socio-cultural and economic impact over Les Sables d'Olonne and the urban and rural district. A large agglomeration is growing, the General Council: corporate image is consolidated.

\subsection{A local "Sailing Olympic Games"}

Vendée Globe is becoming the local "Sailing Olympic Games". The seventh, the last or the last before the biggest one? But local elections can influence the future!. Local politics want to keep a control on this event!...

Sailing in the Vendée Globe round the world race is to experience an extraordinary story, to be part of one of the most prestigious sporting events; to share the experience with the widest audience; to become an ambassador for the most popular sporting events; to promote strong values like courage, ambition, authenticity, determination and solidarity. To become a partner is to gain strong visibility and reinforce your brand awareness; to drive your commercial networks; to enhance company revenue; to unite and drive your teams; to know how to be a step ahead of your competitors.

Each successive innovative Vendée Globe since 1989 has been larger than its predecessor and attracted growing attention both inside and outside, but therefore it must consolidate its position of excellence in France by its impacts, but also enhance its reputation and visibility abroad to be recognized as the major event on the competitive international scene. This event attracts the world's largest groups and now from China and has ensured that the Vendée and the Sables d'Olonne enjoy an impressive reputation. However, a substantial gap remains to be done to align with the America Cup. If we consult the reference number $(1,400,000)$ provided for those wishing to learn more about Vendée Globe on the Google search engine, they are below the total references for The America Cup $(2,380,000)$. This result is verified through linguistic references using existing language tools on line: on one hand 85,000 English references, 75,500 in Deutsch, 29,000 in Chinese, 23,000 in Spanish. And on the other hand, the America's Cup gets 2,380,000 references: German 3,500,000; English 46,300,000; Spanish: 55,700,000; Italians: 22,200,000; Chinese: 28,100,000 results.

Acclaimed and anchored strongly in the territory, it is a common property. However, such success is dangerous for the fishing port, the commercial harbor and the auction fish which risk to be destroyed further to the ambitions of the 
investors and the local elected representatives blinded. The city risks losing its soul there! Acclaimed and anchored strongly in the territory, the Vendée Globe belongs to the Vendée Heritage, it is a common property, yet it lays claim to universal application!

\section{References}

[1] A guide for monitoring and evaluating community-based projects UNESCO 2009.

[2] Boyce W. 1993. Evaluating participation in community programs. An empowerment paradigm. The Canadian Journal of program Evaluation 8: 1, pp. 89-102.

[3] Patton M. 1997. Utilization-focused evaluation 3rd Edition. Thousand Oaks, CA., Sage.

[4] Cynthia. L.M. Chin, Susan A. Moore, Tabatha J. Wallington and Ross K. Dowling 2000 Ecotourism in Baka National Park, Borneo: Visitors' perspectives on environmental impacts and their management in Journal of Sustainable Tourism, Volume 8, No. 1, pp. 20-35. 